ISSN 0975-3311

Ushus JBMgt, 9, 2 (2010) 59-72

ISSN 0975-3311 | https://doi.org/10.12725/ujbm.17.5

\title{
NEW GENERATION BANKS' PROMOTION STRATEGIES FOR BANKING SERVICES
}

\author{
Joseph Sebastian Thekedam*
}

\section{ABSTRACT}

One of the sectors within the service industry that has been influenced the most by the changes in the globalization process, and at the same time has been highly internationalized, is the banking sector. With the growing importance of the financial sector, pressures are escalating for more effective marketing management of the financial services. Despite the recent recessions, the financial services sector is continuing to grow in terms of turnover and profits and thus, has a supreme impact on the other spheres of the economy. Consequently, there is currently growing interest in applying marketing techniques and tools in financial services. The purpose of this study is to gain a better understanding of the new generation banks' promotion strategies in India. For data collection the researcher has used interviews and documentations. This study shows that all promotion tools in the promotion mix are used to some extent for the promotion of banking services. However, personal selling is the most important promotion

* St. Berchmans' College, Changanacherry, Kerala State. E-mail: jsthekkedam@yahoo.com 
tool used for promoting banking services. The external factors that are most influential on the choice of promotion strategy are the cultural aspects, the technology intensity of the industry, the competitive environment of the market and the economic factors. The new generation banks use a contingency approach of the promotion strategy instead of a pure adaptation or a pure standardization strategy for promoting the banking services.

Keywords: Advertising, Sales Promotion, Public Relations, Personal Selling, Direct Marketing, Adaptation and Standardization.

\section{Introduction}

Promotion is the direct way an organization tries to reach its publics. With the growing importance of the financial sector, pressures are escalating for more effective marketing management of the financial services. In spite of major changes on the market of financial institutions, there are indications that banks have not yet successfully embraced the marketing philosophy or achieved levels of its implementation consistent with satisfied customers. Financial institutions are realizing that their established promotion practices are inadequate for new market conditions as levels of customer defection in the sector grow. Traditionally, banks have tried to reach out to everyone in the community, but recent research studies propose that banks should aim to identify and serve micro-segments. (Dawes \& Brown, 2000)

Banks have been encountering numerous challenges including competition, recessions and image problems. Additionally, many banks have been facing mature domestic markets with limited future growth potential. The issues of marketing are becoming more complicated as internationalization of financial services continues to increase. Under these circumstances effective promotion of financial services is crucial for the survival, growth and development of the banks. Promotion of financial services is an understudied area. Much of the bank marketing literature has concentrated on marketing theory more than promotion practice. The main motive for conducting this study is due to the fact that limited research is available within this area.

\section{Objectives of the Study}

The main purpose of this research study is to gain a better understanding of the new generation banks' promotion strategies in the new scenario of 
globalization and internationalization. The other important objectives of the study are the following:

- To study how the banks tries to reach its publics through the five elements of the promotion mix, i.e. advertising, sales promotion, personal selling, public relations, and direct marketing.

- To analyze how the external factors are influencing the choice of promotion strategy for banking services.

- To investigate whether the banks use a pure adaptation or a pure standardization strategy or a contingency approach of the promotion strategy.

\section{Theoretical Frameworks}

Promotion is the direct way in which an organization communicates the product or service to its target audiences. Within the financial services industry, promotion is used in many different ways. The promotional tools can be categorized into five main elements: Advertising, Sales Promotion, Public Relations, Personal Selling, and Direct Marketing

\section{Advertising}

A bank attempting to generate a long term build-up of its name would use institutional advertising, while a bank interested in promoting its brand name and its different services would use a brand advertising policy (Brassington \& Pettitt, 2000). There are two types of advertising channels appropriate for financial advertising. That is "above-the-line" and "underthe-line" advertising. Above-the-line advertising contains different channels of communication, such as television, radio, posters, magazines and newspapers. Under-the-line advertising is the invisible advertising of the bank's services, including leaflets, pamphlets, explanatory guides and manuals that can be used to support selling of a specific service (Meidan, 1996).

\section{Sales Promotion}

Special offers, coupons, and other forms of price manipulation are the dominant forms of sales promotion techniques used by banks. The primary 
objectives with sales promotion within financial services are to attract new customers; to increase the level of deposit accounts, thereby increasing the banks share of savings; to increase market share in selected market segments; and to lower the cost of acquiring new customers by seeking to avoid direct price competition with other financial institutions. (Meidan, 1996)

\section{Public Relations}

The essence of public relations is to look after the nature and quality of the relationship between the organization and its different publics, and to create a mutual understanding. Public relations cover a range of activities, for example the creation and maintenance of corporate identity and image; charitable involvement, such as sponsorship, and community initiatives; media relation for the spreading of good news, as well as for crisis management, such as damage limitation. (Brassington \& Pettitt, 2000)

\section{Personal Selling}

Personal selling can be performed either face-to-face or through technological aids such as the Internet. The relationship between the salesperson and the customer is perceived as being of great importance for the marketing of a bank. Hence, the sales force within the financial services industry needs not only to be trained in the art of selling, but also to be aware of all the services available and be able to clearly explain what each service offers. Since customers' needs and motivation are likely to be complex, and their ability to assess alternative courses of action without professional assistance is likely to be limited, it is of great significance for the sales force to know their customers, as well as their products. (Julian \& Ramaseshan, 1994)

\section{Direct Marketing}

The financial sector can extend its "face-to-face" selling towards direct marketing of products and services in the form of phone, mail, or computer transactions. 


\section{Adaptation and Standardization of the Promotion Strategy}

It is not possible to use either total standardization or complete adaptation in promotion strategy (O.Donnell \& Jeong, 2000). The degree to which these are used depends on a number of internal factors, for example organizational structure and managerial orientation, and external factors, such as target market and environment. Cavusgil et al. (1993) states that standardization and adaptation should be seen as two extremes, and choosing one of these approaches without adjusting it will not be successful.

\section{Relationship Banking}

Relationship banking is part of Relationship Marketing (RM), which aims to create a client relationship from the start to satisfy and keep existing customers (Lindgreen, Davis, Brodie \& Buchanan-Oliver, 2000). Banks moved into relationship banking, because they operate in an intensively competitive environment and offer a wide variety of new services to customers (Zineldin, 1996). According to Heffernan, O'Neill, Travaglione and Droulers (2008) one of the reasons why banks operate in a very competitive market, is because they provide homogenous products and services. Therefore, they need to seek differentiation and they can achieve that through developing good relationships with their customers. The key elements of relationship banking are promise, trust, technology, customer satisfaction, price, loyalty, role of the branch manager or relationship manager, and quality of the service.

\section{Methodology}

This research study is mainly descriptive in nature with both explorative and some explanatory influences. In order to gain a better understanding of banks' promotion strategies the researcher has chosen a qualitative approach that enables to obtain more in-depth information. A case study strategy is used to get an in-depth situational picture. A case study is the preferred strategy when the investigator has little control over events and when the focus is on a contemporary phenomenon within some real-life context. Due to the fact that we draw the conclusions in this research study from the information gathered during the interviews and since the data is full of perceptions and beliefs, the data is non-quantifiable. 


\section{Sample Selection}

The choice of sample technique is dependent on the feasibility and sensibility of collecting data to address the objectives. The researcher has chosen seven new generation banks, Bank of Punjab, Centurion Bank, HDFC Bank, ICICl Bank, IDBI Bank, IndusInd Bank, and UTI Bank. The researcher selected these banks, which operate on the same level to be able to have a better understanding of banks' promotion strategies in the new scenario of globalization and internationalization.

\section{Data Collection Method}

For this study, the researcher regard that the personal interview is a suitable approach due to the fact that selected people will be interviewed within a time limit and with a protocol of questions. This research study has a qualitative approach, due to the fact that the researcher is going to interview selected people from the bank sector and therefore it is not necessary to have a quantitative approach. To get accurate information about the banks' promotion strategies the bank authorities were requested to provide appropriate interview respondents. The researcher decided to interview two respondents each from the seven new generation banks selected for this study. In order to collect secondary data, the researcher visited the different websites of the new generation banks and found general information about them.

\section{Data Analysis}

In order to analyze the data collected, the researcher performed a withincase and cross-case analysis. Applying these two analyzing methods facilitate comprehending the data and relating it to the theory. Within-case analysis is known as comparing the data against the theory applied, while crosscase analysis is comparing data between cases. To increase the reliability a structured interview guide was prepared. In order to increase validity, the structured interview guide was reviewed by the experts in the field and collected feedback from them before conducting the interview. Additionally, during the interviews the researcher further explained some of the questions from the interview guide to avoid confusion. 


\section{Data Analysis}

\section{The Promotion Mix for Banking Services}

The promotion tools analyzed are advertising, sales promotion, public relations, personal selling and direct marketing.

\section{Advertising}

The new generation banks use both institutional and brand advertising to promote their banking services. This is in accordance with the theoretical concept that a financial organization can use both institutional and brand advertising activities and often in combination with each other. Institutional advertising is currently the most frequent form of advertising used by new generation banks in India. Institutional advertising is mostly exposed through television or outside media, such as ad-pillars and posters. Furthermore, television commercials are mainly used for the purpose of building the brand name and brand recognition. However, since the market became aware of new generation banks, advertising in magazines and radio also become significant. In addition, brand advertising, which is concentrated mostly on specific services, is also of great importance. It focuses on reaching the customers who are most likely to be interested in the service, and on being cost efficient. It is performed in order to reach short-term goals such as selling a specific amount of home loans or credit cards within a certain period of time. In order to conduct brand advertising, the target segment is defined, since the aim is to advertise specific services to specific customer segments. Therefore the type of media is chosen. The circulars and magazines are the most commonly used distribution channels whereas television is most widely used media channel.

The new generation banks have divided their advertising into "under-theline" and "above-the-line" advertising. Over-the line advertising is frequently used through poster, magazine and news paper advertising. However, the usages of banners on websites of other companies are also an important way to promote new generation banks services. Under-the -line advertising is commonly used at the offices and sales points. Leaflets, pamphlets, explanatory guides and manuals are made available, either in combination with personal selling or for customer self-senvice. Normally, the new generation banks have a number of advertising campaigns in an year; however this 
depends on the economical and competitive situation on the market. The individual brand advertising campaigns follow the image the bank has created through its institutional advertising in form of having the same color scheme and always using the new generation banks logotypes. Advertising is the second most important promotional tool after personal selling, since it effectively creates awareness of the brand and helps to create a brand image.

\section{Sales Promotion}

The new generation banks use sales promotion to some extent in the form of special offerings and giveaways. New generation banks like IDBI bank is offering for their clients special favours like "free any where banking", attractive rates for home loans, ASBA facilities, free cheque collections and free DD/Pay orders, RTGS and lots more. However, special offerings are not commonly used by the new generation banks and only when the market conditions are favourable. Giveaways are mostly offered to corporate customers and private customers in the upper segment. Examples of giveaways include the new generation banks branded gifts, such as pens, calendars and diaries. These are handed at meetings with the corporate or private customers.

\section{Public Relations}

Public relations are handled by the new generation banks through a number of media and ways, with varying objectives. In order to inform the public about the new generation banks and its products, the company tries to appear in news television programmes to write articles in financial magazines. For the creation of goodwill, the new generation banks are sponsoring a number of social projects, where the main fields include culture, sports and social affairs. The sponsorship principles are based on the objectives established by the new generation banks, as well as the local circumstances, relevance and significance of the supported projects to the whole society or certain social groups. First and foremost integrity, cultural value and social background of the projects are evaluated. The budget and significance of the project as well as the banks' current resources also influence the volume of the sponsorship and the choice of projects. 


\section{Personal Selling}

Personal selling is performed by the new generation banks through the telephone, internet and interaction at the offices. Services such as accounts, credit cards, loans, investment funds and insurance are offered to the customers. In order to effectively manage the personal selling activities, the new generation banks have segmented their customer groups. Customers in the upper segment have their personal banking advisor, as well as corporate customers with a turnover above a certain level also have their own contact person. Additionally, the telephone bank calls customers, mostly from the upper segment, to inform about offerings and new products. Less profitable customers are mostly informed about their offerings via mail. This concept is called one-to-one and one-to-many, and was developed in order to be most cost efficient. Customer relations are also handled. on commission by telemarketing companies who contact the new generation banks customers to inform about offerings or new products. Customers of competing banks are also contacted and provided with information in order to convince them to choose the new generation banks over other banks. Most of the personal selling is performed in the everyday work at the offices. It is commonly used in order to reach customers "right on the spot", for example by promoting the new generation banks services to employees of a firm that is already a customer of the bank. Making "right on the spot" selling is a very central part of the promotion strategy. This is sometimes performed when the customer visits the office for another cause than actually buying a service. However, personal selling is also often performed on request of the customer. The employees working with personal selling annually acquire additional education in order to increase their competence.

\section{Direct Marketing}

The new generation banks normally uses direct marketing in connection with new product launches and special offers. It is mostly conducted through post circulars, but also through telemarketing companies contacting existing and potential customers. The new generation banks have a data base with customer information in order to perform segmentation and targeting efficiently. Firstly, the already existing customers are targeted and thereafter potential customers within the new generation banks' target segment. After deciding which target segment to focus on, the choice of media is made. The new generation banks have extended their "face-to-face" selling towards 
direct marketing of products and services in the form of telephone, mail and computer transactions.

\section{External Factors Influencing the Choice of Promotion Strategy}

With regard to the external factors influencing the choice of promotion strategy for banking services, the external factors like cultural aspects, competition of the market, economic factors and technology orientation of the industry are of great importance when making a decision about new generation banks promotion strategy.

\section{Adaptation and Standardization of the Promotion Strategy}

The analysis of the empirical data reveals that the arguments pro adaptation are the differences in the media scene, the nature of the competition, and the service is at different stages of its life-cycle. The arguments for standardization are cost reduction and economies of scale

\section{Relationship Banking}

The findings from the empirical data collected substantiate the view that for establishing a long term relationship requires several factors to take into consideration. First of all there is the trust between the branch manager and the customer. For the new generation banks this is a factor of high importance. The trust is an essential part of relationship banking due to the fact that there is a high similarity in the products and services offered in the bank sector. It is not difficult for a customer to switch banks, but once trust is built they will more likely to stay. Therefore, the data collected supports the theory that trust is an essential part of relationship banking. The technology is not as vital as the trust because banking about human contact and interaction. Therefore, the technology does not have a high level of importance. However it will facilitate in some aspects such as: finding new potential customers, helps the branch managers with recommendations for the customer and virtual banking. Customers are more price sensitive and they would switch bank because of the price difference. In new generation banks the price varied depending on the service the customer utilized. Loyalty is an aspect the new generation banks focus on. Along with trust, loyalty is an essential factor that will be an outcome of a strong and close relationship. Satisfying the customer is the main target for the new generation banks. A satisfied customer is a customer who will return and use more 
services. If the customer is not satisfied and happy with the banking, they will most likely find another bank for further transactions in the future. The branch manager has a significant and important role in banking. They are the key factor in relationship banking, due to the fact that they are the first with whom the customers contact. Their task is to establish a strong relationship and have a responsibility to assure that the customer's needs and preferences are met and fulfilled. Lastly, the quality is certainly an important factor. As mentioned earlier, the bank's services and products are homogeneous which makes them very competitive. For that reason, the quality has a large impact on if the customer returns or not.

\section{Conclusions}

The research study shows that all parts of the promotion mix are used to some extent for promotion of banking services. Personal selling is considered to be the most important promotional tool, as it aims to build relationships between the customer and the bank. Relationships are crucial, since they make the customer loyal to the brand and enable the bank to reach its long-term goals. Concerning advertising banks use both institutional and brand advertising. Institutional advertising is conducted for brand building, which is vital due to the fact that all banks offer similar products. It is of great importance to have a strong brand in order to attract customers. Institutional advertising is conducted through television, magazines and outdoor media, in order to combine a strategy that reaches a broad crowd and that is somewhat cost efficient. Thereby less profitable and potential customers are also targeted. The brand advertising aims specific services towards specific customer segments. Banks tend to be selective when it comes to promoting specific services and they focus on their primary customers. Brand advertising is primarily used in order to reach short term goals. Above-the-line and under-the-line advertising are both of importance for banks. A combination of the two in their promotion strategy is preferable, as they are a great complement to one and other. Furthermore, under-theline promotion is an essential complement for personal selling, since it provides the customer with information regarding the different services that are offered. Banks are careful in their use of sales promotion. However, special offerings and other forms of price manipulation are used to some extent. Public relations are performed in order to create goodwill and to spread information. This is done through participation in business magazines as well as via sponsoring of social projects. The aim of direct 
marketing is to inform as well as to promote. It is commonly used through post circulars, but the use of internet is also considered to be of importance.

From the case analysis the following conclusions are drawn:

- All promotion tools in the promotion mix are used to some extent for the promotion of banking services.

- Personal selling is the most important promotion tool when promoting banking services.

- Segmentation of customers is an essential part of the promotion for banking services.

- A strong brand is crucial in order to attract customers.

Concerning the external factors influencing the choice of promotion strategy, the researcher found that theory and empirical findings to a great extent corresponded. The cultural aspects factor is the most important external factor influencing the choice of promotion strategy. The other external factors that influence the choice of promotion strategy are the technology orientation of the industry, the competitiveness of the market and the economic factors.

Banks use neither a pure adaptation nor a pure standardization strategy and therefore the conclusion is that a contingency approach of the promotion strategy is applied. The most important reason for adapting is the different customer preferences and expectations. Adaptation is carried out with regard to media, language, competition and stage in the life cycle of the bank as a brand. The most important reason for standardizing is cost-reduction and economies of scale. Our empirical findings points out that a lot of material, especially connected to personal selling should be standardized. Another important reason for standardizing is the creation of a consistent and uniform brand image.

\section{Implications}

- Managers who wish to conduct promotion should focus on personal selling, since it is the most important promotion tool and it involves establishment of relationships with individual customers. It is of great importance to provide specific education for the sales personnel, since they are the ones interacting with customers, and thereby affecting 
customer perception of the bank. Advertising should also be emphasized due to its ability to reach a broader public and create awareness and interest among potential customers. The remaining three promotion tools are also applicable, and should be used as a complement to personal selling and advertising.

- The factors that are most influential on the choice of promotion strategy, and therefore should be taken into extra consideration, are the cultural aspects, the technology intensity of the industry, the competitive environment of the market and the economic factors involved.

- Managers should attempt to standardize their promotion to the extent possible, in order to diminish expenses and achieve economies of scale. However due to differing preferences and expectations of the customers, a great deal of the promotion must be adapted.

\section{Implications for Further Research}

- Since our study only focuses on one element of the marketing mix, namely promotion, it would be of interest to conduct a study of the other three elements, i.e. price, place and product.

- Another interesting field of study is brand management within the banking industry.

- It should also be of interest to study how the Internet should be used as a marketing tool for banks in the most efficient way.

\section{References}

Albers-Miller, N.D. \& Straughan R.D. (2000). Financial Services Advertising in Eight nonEnglish Speaking Countries, International Journal of Bank Marketing, Vol. 18 No. 7 , pp. 347-358.

Brassington, F. \& Pettitt, S (2000). Principles of Marketing, $2^{\text {nd }}$ Edition, Harlow: Pearson Education Limited.

Cavusgil, S.T., Zou, S. \& Naidou, G.M. (1993). Product and Promotion Adaptation in Export Ventures: An empirical Investigation, Journal of International Business Studies, Vol.24, No. 3 .

Dawes, J. \& Brown, R.B. (2000). Postmodern Marketing: Research Issues for Retail Financial Services. Qualitative Market Research: An International Journal, Volume 3, No. 2, pp. 90-98. 
De Mooii, M. (1994). Advertising Worldwide. $2^{\text {nd }}$ Edition, Trowbridge: Prentice Hall

Heffernan, $\mathrm{O}^{\prime}$ Neill, Travaglione and Droulers (2008). Relationship marketing. The impact of emotional intelligence and trust on bank performance. International Journal of Bank Marketing, Vol. 26 (3), pp. 183-199.

Joseph, B., Joseph, M. \& McClure, C. (1999). Service Quality in the Banking Sector: the Impact of Technology on Service Delivery, International Journal of Bank Marketing, Vol. 17 No. 4, pp. 182-193.

Julian, C.C. \& Ramaseshan, B. (1994). The Role of Customer-contact Personnel in the Marketing of a Retail Bank's Services. International Journal of Retail \& Distribution Management, Vol. 22No. 5, pp. 29-34.

Lee, J. (2002). A Key to Marketing Financial Services: the Right Mix of Products, Services, Channels and Customers. Journal of Services Marketing, Vol. 16 No. 3, pp. 238258.

Lindgreen, A., Davis, R., Brodie, R.J., \& Oliver, M.B. (2000). Pluralism in contemporary marketing practices. International Journal of Bank Marketing, Vol. 18 (6), pp. 294 308.

McLaughlin, C. P. \& Fitzsimmons, J.A. (1996). Strategies for Globalizing Service Operations. International Journal of Service Industry Management, Vol. 7 No. 4, pp. 43-57.

Meidan, A. (1996). Marketing Financial Services, Hampshire and London: Macmillan Press Ltd.

Mortimer, K., (2001). Services Advertising: the Agency Viewpoint. Journal of Services Marketing, Vol. 15 No. 2, pp. 131-146.

O'Donnell, S. \& Jeong, I. (2000) Marketing Standardization within Global Industries. International Marketing Review, Vol. 17, No. 1, pp. 9-33.

Papavassiliou, N. \& Stathakopoulus, V. (1997). Standardization vs. Adaptation of International Advertising Strategies: Towards a Framework. European Journal of Marketing, Vol. 32, No. 7, pp. 504-527.

Van Mesdag, M. (2000). Culture-Sensitive Adaptation or Global Standardization-the Duration of Usage Hypothesis, International Marketing Review, Vol. 17, No. 1, pp. 74-84.

Yin, R.K. (1994), Case Study Research, Design and Methods, 2 ${ }^{\text {nd }}$ Edition, Thousand Oaks: Sage Publications, Inc.

Zineldin, M., (1996). Bank-corporate client "partnership" relationship: benefits and life cycle. International Journal of Bank Marketing, Vol. 14 (3), pp. 14-22. 